\title{
PENGARUH LEVERAGE DAN PROFITABILITAS TERHADAP NILAI PERUSAHAAN DENGAN KEBIJAKAN DIVIDEN SEBAGAI VARIABEL MODERATING PADA PERUSAHAAN MANUFAKTUR YANG TERDAFTAR DI BURSA EFEK INDONESIA TAHUN 2010 - 2014
}

\author{
Oleh: \\ Sisca \\ Dosen STIE Sultan Agung Pematangsiantar
}

Abstrak

Penelitian ini bertujuan untuk membuktikan dan menganalisis pengaruh Leverage (DER) dan Profitabilitas (ROE) terhadap Nilai Perusahaan (Tobin's $Q$ ) pada perusahaan manufaktur yang terdaftar di Bursa Efek Indonesia, serta ingin membuktikan dan menganalisis Kebijakan Dividen (DPR) mampu memoderasi hubungan antara Leverage dan Profitabilitas terhadap Nilai Perusahaan. Populasi dari penelitian ini adalah seluruh perusahaan manufaktur yang terdaftar di Bursa Efek Indonesia (BEI) tahun 2010-2014 sebanyak 149 perusahaan. Teknik pengambilan sampel yang digunakan adalah metode purposive sampling, sehingga menghasilkan 36 perusahaan sebagai sampel penelitian. Data penelitian merupakan data sekunder yang diperoleh dari Indonesian Stock Exchange (www.idx.co.id) dan ICMD tahun 2010-2014. Pengujian hipotesis penelitian dilakukan dengan menggunakan analisis regresi berganda untuk hipotesis pertama dan analisis regresi variabel moderasi untuk hipotesis kedua, dengan alat bantu software SPSS for Windows Version 20.0.

Hasil penelitian untuk hipotesis pertama menunjukkan bahwa Leverage, Profitabilitas dan Kebijakan Dividen secara simultan berpengaruh positif dan signifikan terhadap Nilai Perusahaan pada perusahaan manufaktur yang terdaftar di Bursa Efek Indonesia tahun 2010-2014, sedangkan secara parsial hanya Profitabilitas yang berpengaruh positif dan signifikan terhadap Nilai Perusahaan pada perusahaan manufaktur yang terdaftar di Bursa Efek Indonesia tahun 2010-2014. Hasil dari hipotesis kedua menunjukkan bahwa Kebijakan Dividen tidak mampu memoderasi pengaruh Leverage dan Profitabilitas terhadap Nilai Perusahaan pada perusahaan manufaktur yang terdaftar di Bursa Efek Indonesia tahun 2010-2014.

Kata Kunci : Leverage, Profitabilitas, Nilai perusahaan dan Kebijakan Dividen

Abstraction

The objective of this research was to verify and analyze the influence of Leverage (DER) and Profitability (ROE) on the Firm Value (Tobin's Q) in manufacturing companies listed in Indonesian Stock Exchange, as well as to verify and analyze whether Dividend Policy (DPR) was able to moderate the correlation between Leverage and Profitability with Firm Value. The population of this research was all manufacturing companies listed in Indonesian Stock Exchange (BEI) in 2010-2014 which total was 149 companies. The sample was selected by using purposive sampling method, which resulting in 36 companies as research samples. The research data was secondary data which was obtained from the Indonesian Stock Exchange (www.idx.co.id) and ICMD in 20102014. Research hypothesis were tested by using multiple regression analysis for the first hypothesis and regression analysis with moderating variable for the second hypothesis, by using the software tool SPSS for Windows Version 20.0 to calculate the data.

The results of the first hypothesis showed that Leverage and Profitability simultaneously had positive and significant influence on Firm Value in manufacturing companies listed in Indonesian Stock Exchange in 20102014, while partially, only Profitability had positive and significant influence on Firm value in the manufacturing companies listed in the Indonesian Stock Exchange in 2010-2014. The result of second hypothesis showed that Dividend Policy was not able to moderate the correlation between Leverage and Profitability with Firm Value in manufacturing companies listed in Indonesian Stock Exchange in 2010-2014.

Keywords: Leverage, Profitability, Firm Value and Dividend Policy

\section{A. PENDAhuluan}

1. Latar Belakang Masalah

Pada umumnya, alasan utama dari dibentuknya atau didirikannya sebuah perusahaan adalah untuk meningkatkan kemakmuran para pemegang saham. Adapun cara mengukur tingkat kemakmuran para pemegang saham adalah melalui nilai perusahaan. Nilai perusahaan merupakan nilai pasar atas surat berharga utang dan ekuitas perusahaan yang beredar. Nilai perusahaan dapat memberikan kemakmuran pemegang saham secara maksimum apabila harga saham meningkat, dimana semakin tinggi harga saham sebuah perusahaan, maka nilai perusahaan dan kemakmuran para pemegang saham juga meningkat. Pengukuran nilai perusahaan dalam penelitian ini menggunakan proksi Tobin's $Q$. Tobin's $Q$ merupakan salah satu rasio keuangan yang cukup representatif untuk melihat penciptaan nilai oleh suatu perusahaan, dimana semakin tinggi rasio ini berarti pasar percaya akan prospek perusahaan tersebut. 
Leverage mengukur kemampuan perusahaan untuk memenuhi seluruh kewajiban finansialnya yang terdiri dari utang jangka pendek dan utang jangka panjangnya. Leverage dalam penelitian ini diproksikan oleh DER (Debt to Equity Ratio) yang merupakan perbandingan jumlah pinjaman jangka panjang yang dimiliki perusahaan dengan jumlah modal sendiri. Dengan demikian, semakin besar DER maka akan semakin kecil laba yang dapat dibagikan kepada pemegang saham, sehingga dapat menurunkan harga saham yang bersangkutan. Semakin rendah tingkat DER maka kemungkinan nilai perusahaan akan semakin tinggi dan perusahaan akan mendapat kepercayaan dari investor.

Nilai perusahaan dapat dipengaruhi oleh besar kecilnya profitabilitas yang dihasilkan oleh perusahaan. Rasio profitabilitas dalam penelitian ini diproksikan oleh ROE (Return On Equity). ROE digunakan untuk mengukur kemampuan perusahaan dalam menghasilkan laba bersih setelah pajak berdasarkan modal sendiri. Semakin tinggi ROE menunjukkan bahwa semakin tinggi tingkat pengembalian terhadap investasi yang dilakukan dan semakin rendah ROE suatu perusahaan maka tingkat pengembaliannya akan semakin rendah pula. Sehingga dapat dikatakan, semakin tinggi nilai ROE maka semakin baik kondisi perusahaan, semakin besar pula penghasilan yang diperoleh perusahaan dan akan meningkatkan harga saham perusahaan yang bersangkutan. Jadi, dapat disimpulkan bahwa profitabilitas mempunyai korelasi positif terhadap nilai perusahaan

Kebijakan dividen pada dasarnya adalah penentuan besarnya porsi keuntungan yang akan diberikan kepada pemegang saham. Besarnya dividen ini dapat mempengaruhi harga saham. Apabila dividen yang dibayar tinggi, maka harga saham cenderung tinggi sehingga nilai perusahaan juga tinggi. Sebaliknya jika dividen yang dibayarkan kecil maka harga saham perusahaan tersebut juga rendah. Kebijakan dividen dalam penelitian ini menggunakan proksi Dividend Payout Ratio (DPR). DPR merupakan persentase dari pendapatan yang akan dibayarkan kepada pemegang saham sebagai cash dividend.

\section{Rumusan Masalah}

a. Apakah leverage dan profitabilitas berpengaruh positif dan signifikan terhadap nilai perusahaan baik secara simultan maupun parsial pada perusahaan manufaktur yang terdaftar di Bursa Efek Indonesia tahun 2010 - 2014?

b. Apakah kebijakan dividen mampu memoderasi hubungan antara leverage dan profitabilitas terhadap nilai perusahaan pada perusahaan manufaktur yang terdaftar di Bursa Efek Indonesia tahun 2010 - 2014?

\section{Tujuan Penelitian}

a. Untuk membuktikan dan menganalisis pengaruh leverage dan profitabilitas terhadap nilai perusahaan baik secara simultan maupun parsial pada perusahaan manufaktur yang terdaftar di Bursa Efek Indonesia tahun 2010 - 2014.

b. Untuk membuktikan dan menganalisis kebijakan dividen (variabel moderating) mampu memoderasi hubungan antara leverage dan profitabilitas terhadap nilai perusahaan pada perusahaan manufaktur yang terdaftar di Bursa Efek Indonesia tahun 2010 - 2014.

\section{Metode Penelitian}

Lokasi penelitian ini dilakukan pada perusahaan manufaktur yang terdaftar di Bursa Efek Indonesia (BEI) pada periode pengamatan yaitu tahun 2010-2014. Teknik pengambilan sampel yang digunakan oleh peneliti adalah metode purposive sampling dengan sampel yang digunakan dalam penelitian ini adalah perusahaan manufaktur yang terdaftar di Bursa Efek Indonesia (BEI) pada periode pengamatan yaitu tahun 2010 sampai dengan 2014 yang telah memenuhi kriteria yaitu sebanyak 36 perusahaan.

Adapun desain penelitian yang digunakan dalam penelitian ini adalah jenis penelitian eksplanatori yang menjelaskan hubungan kausal antar variabel melalui pengujian hipotesis, yakni menjelaskan pengaruh variabel bebas yakni Leverage $\left(\mathrm{X}_{1}\right)$, Profitabilitas $\left(\mathrm{X}_{2}\right)$ terhadap variabel tidak bebas yaitu Nilai Perusahaan (Y) dengan variabel pemoderasi yaitu Kebijakan Dividen (Z). Teknik dalam mengumpulkan data untuk penelitian ini adalah dengan menggunakan sumber data eksternal yaitu terbitan yang dikeluarkan oleh Pusat Referensi Pasar Modal seperti Bursa Efek Indonesia (www.idx.co.id) dan Indonesian Capital Market Directory (ICMD) yaitu berupa laporan keuangan perusahaan. Hasil data yang diperoleh akan dianalisis secara deskriptif baik bersifat kualitatif dan kuantitatif.

\section{B. LANDASAN TEORI}

\section{Nilai Perusahaan}

Menurut Keown, et.al. (2004:470), nilai perusahaan adalah nilai pasar atas surat berharga hutang dan ekuiti perusahaan yang beredar. Nilai pasar merupakan persepsi investor terhadap perusahaan yang selalu dikaitkan dengan harga saham. Harga saham yang tinggi membuat nilai perusahaan juga tinggi. Menurut Brigham dan Joel (2012:151), rasio nilai perusahaan yang wajar adalah sama dengan satu, artinya harga saham dari perusahaan tersebut seharusnya dihargai oleh investor sesuai dengan nilai bukunya. Berdasarkan uraian di atas maka dapat disimpulkan bahwa nilai perusahaan berkaitan dengan harga saham. Jika harga saham suatu perusahaan tinggi maka nilai perusahaan juga tinggi, dan sebaliknya. Nilai perusahaan yang tinggi menjadi keinginan setiap para pemilik perusahaan, karena dengan nilai perusahaan yang tinggi menunjukkan tingkat kemakmuran pemegang saham juga tinggi.

Dalam penelitian ini nilai perusahaan diukur dengan menggunakan nilai Tobin's $Q$. Tobin's $Q$ 
adalah perbandingan antara market value of equity ditambah dengan hutang (debt) dengan book market value ditambah dengan hutang (debt). Nilai perusahaan yang diukur melalui Tobin's $Q$, diformulasikan sebagai berikut :

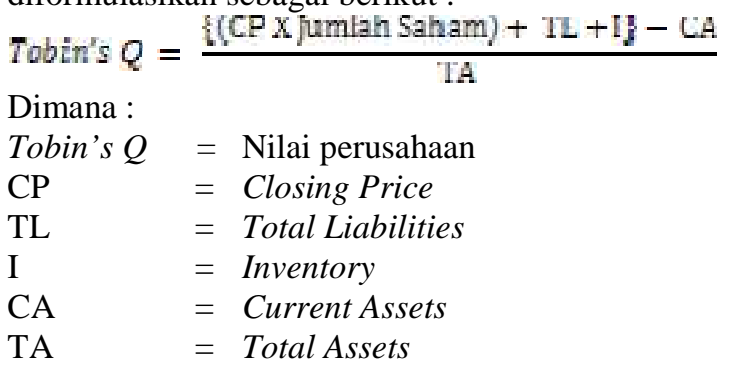

\section{Leverage}

Menurut Stice et al, (2009:145), kebijakan hutang sering diukur dengan debt ratio (rasio utang) yang dihitung sebagai total kewajiban dibagi dengan total aset. Rasio ini menunjukkan besarnya hutang yang digunakan untuk perusahaan dalam rangka menjalankan aktivitas operasionalnya. Margaretha (2011:26), mengungkapkan bahwa rasio leverage merupakan kemampuan perusahaan untuk melunasi hutang. Semakin besar rasio ini menunjukkan semakin besar tingkat ketergantungan perusahaan terhadap pihak eksternal (kreditor) dan semakin besar biaya utang yang harus dibayar perusahaan.

Adapun jenis-jenis rasio leverage yang umumnya digunakan, diantaranya terdiri dari:

a. Debt to Assets Ratio (Debt Ratio)

Merupakan rasio utang yang digunakan untuk mengukur seberapa besar aset perusahaan dibiayai oleh hutang atau seberapa besar utang perusahaan berpengaruh terhadap pengelolaan aset (Kasmir, 2010:112). Rasio ini dapat dihitung dengan rumus:

Debt to Assets Ratio $=$ Total Debt Total Assets

b. Debt to Equity Ratio (DER)

Merupakan rasio yang digunakan untuk menilai utang dengan ekuitas. Rasio ini berguna untuk mengetahui jumlah dana yang disediakan peminjam (kreditur) dengan pemilik perusahaan (Kasmir, 2010:112). Untuk mencari rasio ini yaitu dengan membandingkan seluruh hutang, termasuk hutang lancar dengan seluruh ekuitas. Rasio ini dapat dihitung dengan rumus:

$$
\text { Debt to Equity Ratio }=\frac{\text { Total Debt }}{\text { Equity }}
$$

c. Long Term Debt to Equity Ratio

Merupakan rasio antara hutang jangka panjang dengan modal sendiri. Rasio ini mengukur besar kecilnya penggunaan hutang jangka panjang dibandingkan dengan modal sendiri perusahaan. Rasio ini dapat dihitung dengan menggunakan rumus:

d. Time Interest Earned (TIE)
Merupakan rasio yang digunakan untuk mengukur kemampuan perusahaan untuk membayar beban tetap berupa bunga dengan menggunakan Earning Before Interest and Tax (EBIT). Menurut Brigham dan Joel (2012:144), rasio Time Interest Earned (TIE) mengukur sejauh apa laba operasi dapat mengalami penurunan sebelum perusahaan tidak mampu memenuhi biaya bunga tahunannya. Time Interest Earned (TIE) dapat dihitung dengan menggunakan rumus:

$$
\text { Time Interest Earned }=\frac{\text { EBIT }}{\text { BiayaBunga }(\text { Interest })}
$$

e. Fixed Charge Coverage

Rasio ini sama halnya seperti Time Interest Earned. Hanya saja bedanya rasio ini dilakukan apabila perusahaan memperoleh hutang jangka panjang atau menyewa aset berdasarkan kontrak sewa (Kasmir, 2010:113). Rasio ini dapat dihitung dengan rumus sebagai berikut:

$$
\text { Fixed Charge Coverage }=\frac{\text { EBT }+ \text { Interest }+ \text { Lease }}{\text { Interest }+ \text { Lease }}
$$

Dalam penelitian ini, penulis memilih DER (Debt to Equity Ratio) sebagai parameter leverage. Alasan peneliti menggunakan DER karena rasio ini mengukur seberapa besar kemampuan perusahaan melunasi hutang dengan modal yang dimiliki, dimana semakin rendah rasio akan semakin baik kemampuan perusahaan dalam membayar kewajiban jangka panjang.

\section{Profitabilitas}

Menurut Sudana (2011:22), profitabilitas adalah rasio untuk mengukur kemampuan perusahaan untuk menghasilkan laba dengan menggunakan sumber-sumbernya yang dimiliki perusahaan, seperti aktiva, modal, atau penjualan perusahaan. Menurut Brigham dan Joel (2006:285), profitabilitas adalah hasil bersih dari serangkaian kebijakan dan keputusan. Berdasarkan pengertian di atas dapat ditarik kesimpulan bahwa profitabilitas merupakan sejauh mana perusahaan mampu memperoleh laba untuk menjamin keberlangsungan hidup perusahaan dan juga sebagai dasar untuk pembagian dividen. Dimana apabila perusahaan mampu menghasilkan laba yang besar, kemungkinan menarik investor untuk memperluas usahanya juga semakin besar.

Menurut Horne dan John (2012:180), rasio profitabilitas dalam kaitannya dengan investasi adalah sebagai berikut:

a. Return on Investment (ROI) atau Return on Assets (ROA)

Return on Investment adalah rasio yang mengukur imbal hasil atas suatu investasi ataupun imbal hasil atas aset yang dimiliki. Dengan demikian ROI dapat dirumuskan:

Keturn un Invastmant $(\mathrm{kUL})=$ Laba Neto setelah pajak

b. Daya untuk Menghasilkan Laba (Earning Power) 
Earning Power adalah rasio yang mengukur imbal hasil sebelum bunga dan pajak atas suatu investasi. Oleh karenanya Earning Power dapat dirumuskan:

Eornang Powar = Prontaburas renyulan $\mathrm{x}$ Engensi Ase

c. Return on Equity (ROE)

Return On Equity membandingkan laba neto setelah pajak (dividen saham biasa) dengan ekuitas yang telah diinvestasikan pemegang saham di perusahaan. Rasio ini menunjukkan daya untuk menghasilkan laba atas investasi berdasarkan nilai buku para pemegang saham. Rumus dari Return on Equity yaitu:

$$
\text { Keturn un Equsty = } \frac{\text { Laba setelah pajak }}{\text { Ekuitas pemegangsahar }}
$$

Dalam penelitian ini, penulis memilih Return on Equity (ROE) sebagai parameter profitabilitas. Alasan peneliti menggunakan ROE karena rasio ini menunjukkan tingkat pengembalian yang diperoleh pemilik atau pemegang saham atas investasinya di perusahaan, dimana semakin tinggi nilai ROE maka semakin baik kondisi perusahaan, semakin besar pula penghasilan yang diperoleh perusahaan dan akan meningkatkan harga saham perusahaan yang bersangkutan.

\section{Kebijakan Dividen}

Menurut Astuti (2004:145), kebijakan dividen menyangkut keputusan untuk membagi laba atau menahannya guna diinvestasikan kembali di dalam perusahaan. Sedangkan menurut Sartono (2008:281), kebijakan dividen adalah keputusan apakah laba yang diperoleh perusahaan akan dibagikan kepada pemegang saham sebagai dividen atau ditahan dalam bentuk laba ditahan guna pembiayaan investasi di masa yang akan datang.

Dari pengertian di atas, maka dapat disimpulkan bahwa kebijakan dividen adalah keputusan apakah laba yang diperoleh perusahaan akan dibagikan kepada pemegang saham dalam bentuk dividen atau sebagai saldo laba untuk menambah modal guna pembiayaan investasi di masa yang akan datang. Berdasarkan keterangan tersebut, proksi yang digunakan untuk mengukur kebijakan dividen dalam penelitian ini dipresentasikan dalam bentuk rasio. Jenis rasio yang digunakan dalam penelitian ini adalah Dividend Payout Ratio (DPR). Berikut ini rumus untuk mengukur Dividend Payout Ratio (DPR) menurut Atmaja (2008:285) :

$$
D P K=\frac{\text { Dividend }}{\text { Net Income }}
$$

\section{Pengaruh Leverage Terhadap Nilai} Perusahaan

Menurut Kasmir (2010:158), leverage akan menunjukkan besarnya modal sendiri yang dijadikan untuk jaminan hutang. Leverage dalam penelitian ini diwakili oleh Debt to Equity Ratio (DER). Semakin besar rasio ini menunjukkan bahwa semakin besar struktur modal yang berasal dari hutang digunakan untuk mendanai ekuitas yang ada. Dimana semakin kecil rasio DER, semakin baik kemampuan perusahaan untuk dapat bertahan dalam kondisi yang buruk. Rasio DER yang kecil menunjukkan bahwa perusahaan masih mampu memenuhi kewajibannya kepada kreditur.

Kebijakan hutang akan memberikan dampak pada pendisiplinan manajer untuk mengoptimalkan penggunaan dana yang ada karena hutang yang cukup besar akan menimbulkan kesulitan keuangan dan atau risiko kebangkrutan sehingga berpengaruh terhahap nilai perusahaan tersebut di mata para investor. Dimana dapat dikatakan bahwa semakin kecil rasio hutang (leverage) perusahaan, maka kemampuan perusahaan untuk membayar dividen juga akan semakin tinggi dan nilai perusahaan yang tercermin dalam harga saham perusahaan akan semakin meningkat, karena tingkat kepercayaan investor terhadap perusahaan akan semakin meningkat.

\section{Pengaruh Profitabilitas Terhadap Nilai} Perusahaan

Setiap perusahaan yang didirikan, tentu diorientasikan untuk memperoleh laba dengan tidak mengorbankan kepentingan pelanggan untuk mendapatkan kepuasan. Perusahaan dengan prospek yang baik ini yang diinginkan oleh investor dan membuat investor lebih tertarik untuk membeli saham. Semakin tinggi permintaan dari investor terhadap saham maka akan mempengaruhi harga saham dan akan meningkatkan nilai perusahaan. Sehingga semakin tinggi profitabilitas perusahaan maka akan semakin tinggi nilai perusahaan.

Teori yang dikemukakan oleh Modigliani dan Miller (1961) dalam Atmaja (2008:285), menyatakan bahwa nilai perusahaan ditentukan oleh profitabilitas perusahaan. Hal ini positif menunjukkan bahwa semakin tinggi profitabilitas semakin tinggi profit margin yang diperoleh perusahaan. Hal ini akan berdampak pada nilai perusahaan. Semakin tinggi tingkat profitabilitas suatu perusahaan maka semakin besar tingkat kemakmuran yang diberikan perusahaan kepada pemegang saham. Semakin besar tingkat kemakmuran yang diberikan oleh perusahaan tersebut dan akan memberikan pengaruh positif terhadap harga saham di pasar. Ini berarti akan menaikkan nilai perusahaan.

\section{Pengaruh Kebijakan Dividen Terhadap} Nilai Perusahaan

Pada umumnya tujuan investor melakukan investasi saham adalah untuk mendapatkan keuntungan yaitu capital gain ataupun dividen. Dalam hal ini pemegang saham berharap untuk mendapatkan dividen dalam jumlah yang besar atau minimal relatif sama setiap tahun. Perusahaan juga menginginkan laba ditahan dalam jumlah relatif besar agar leluasa melakukan reinvestasi. Perusahaan harus dapat mengalokasikan laba bersihnya dengan bijaksana untuk memenuhi dua kepentingan yang berbeda. Pembuatan keputusan yang tepat dalam kebijakan dan pembayaran dividen dapat 
memaksimalkan nilai perusahaan dan nilai para pemegang saham.

Kebijakan dividen dalam penelitian ini dapat dilihat dari nilai Dividend Payout Ratio (DPR) yang merupakan bagian dari laba bersih perusahaan yang dibagikan sebagai dividen. Menurut Gordon dan Linther (1963) dalam Brigham dan Joel (2006:70) berdasarkan Theory Bird In The hand, besarnya dividen yang dibagikan kepada para pemegang saham akan menjadi daya tarik bagi pemegang saham karena sebagian investor cenderung lebih menyukai dividen dibandingkan dengan Capital Gain karena dividen bersifat lebih pasti. Banyaknya investor yang berinvestasi di perusahaan tersebut dapat menyebabkan meningkatnya harga saham sehingga dengan meningkatnya harga saham akan meningkatkan nilai perusahaan itu sendiri. Jadi kebijakan dividen yang ditetapkan oleh perusahaan dapat mempengaruhi nilai perusahaan.

\section{PEMBAhasan}

1. Analisis Data

a. Analisis Deskriptif

Tabel 1

Statistik Deskriptif

\begin{tabular}{|l|c|r|r|r|r|}
\hline & N & Minimum & Maximum & Mean & \multicolumn{1}{c|}{$\begin{array}{c}\text { Std. } \\
\text { Deviation }\end{array}$} \\
\hline LEV_X1 & 180 &, 04 & 3,03 &, 7293 &, 56506 \\
PRO_X2 & 180 &, 42 & 142,30 & 22,0968 & 20,83967 \\
KD_M & 180 &, 05 & 1122,65 & 52,2742 & 94,24321 \\
NP_Y & 180 &,- 29 & 55,82 & 2,4767 & 4,70776 \\
Valid N & 180 & & & & \\
(listwise) & 180 & & & & \\
\hline
\end{tabular}

Sumber: Hasil Output SPSS 20.0 (Data diolah 2016)

Berdasarkan statistik deskriptif yang tersaji pada tabel 1 menunjukkan bahwa data yang digunakan dalam penelitian ini sangat bervariasi. Hal ini mengindikasikan bahwa data penelitian ini mungkin tidak berdistribusi normal. Tabel 1 menunjukkan nilai minimum leverage dalam kurun waktu 2010-2014 yaitu sebesar 0,04. Leverage terendah dimiliki oleh emiten PT Indofood CBP Sukses Makmur Tbk. (ICBP) pada tahun 2011. Tingkat leverage maksimum sebesar 3,03 dimiliki oleh emiten PT Multi Bintang Indonesia Tbk. (MLBI) pada tahun 2014. Hal ini menunjukkan bahwa tingkat leverage perusahaan mengalami fluktuasi setiap tahun. Nilai rata-rata leverage menunjukkan bahwa rata-rata rasio utang perusahaan sampel dibandingkan dengan modalnya adalah sebesar 0,7293 (72,93\%) dengan standar deviasi sebesar 0,56506

Selanjutnya, profitabilitas menunjukkan nilai minimum dalam kurun waktu 2010-2014 yaitu sebesar $0,42 \%$ yang dimiliki oleh emiten PT Indo Kordsa Tbk. (BRAM) pada tahun 2011. Tingkat profitabilitas maksimum sebesar $142,30 \%$ dimiliki oleh emiten PT Multi Bintang Indonesia Tbk. (MLBI) pada tahun 2014. Hal ini menunjukkan bahwa penggunaan hutang pada PT Multi Bintang Indonesia Tbk. ternyata mampu meningkatkan laba perusahaan. Nilai rata-rata profitabilitas menunjukkan bahwa rata-rata perusahaan sampel dalam menghasilkan laba dengan memanfaatkan modal perusahaan untuk operasi perusahaan adalah sebesar $22,0968 \%$ dengan standar deviasi sebesar $20,83967 \%$

Pada variabel kebijakan dividen, nilai minimum dalam kurun waktu 2010 - 2014 yaitu sebesar $0,05 \%$ yang dimiliki oleh emiten PT Gudang Garam Tbk. (GGRM) pada tahun 2012. Tingkat kebijakan dividen maksimum sebesar 1122,65\% dimiliki oleh emiten PT Indo Kordsa Tbk. (BRAM) pada tahun 2011 yang menunjukkan meskipun memiliki tingkat laba terendah pada tahun 2011 tetapi PT Indo Kordsa Tbk. (BRAM) tetap mempertahankan pemberian tingkat dividen yang tinggi dengan tujuan untuk menarik lebih banyak investor untuk menanamkan modalnya di perusahaan tersebut. Nilai rata-rata kebijakan dividen adalah sebesar $52,2742 \%$ yang menunjukkan bahwa ratarata rasio pembagian dividen perusahaan sampel sebesar 52,2742\% dibandingkan dengan laba bersihnya dengan standar deviasi sebesar $94,24321 \%$.

Untuk variabel nilai perusahaan, nilai minimum dalam kurun waktu 2010 - 2014 yaitu sebesar $-0,29$ yang dimiliki oleh emiten PT Sumi Indo Kabel Tbk. (IKBI) pada tahun 2014. Nilai perusahaan maksimum dimiliki oleh emiten PT Indofood Sukses Makmur Tbk. (INDF) pada tahun 2014 sebesar 55,82. Hal ini menunjukkan bahwa pada tahun tersebut, PT Indofood Sukses Makmur Tbk diperkirakan oleh pasar memiliki tingkat pengembalian terbesar dari investasi inkrementalnya yang menjadikannya lebih diminati oleh para investor. Nilai rata-rata nilai perusahaan menunjukkan bahwa rata-rata tingkat pengembalian perusahaan sampel dari investasi inkrementalnya adalah sebesar 2,4767 (247,67\%) dengan standar deviasi sebesar 4,70776.

b. Hasil Analisis Data Hipotesis Pertama

1) Analisis Regresi Berganda

\section{Tabel 2}

Hasil Analisis Regresi Hipotesis Pertama

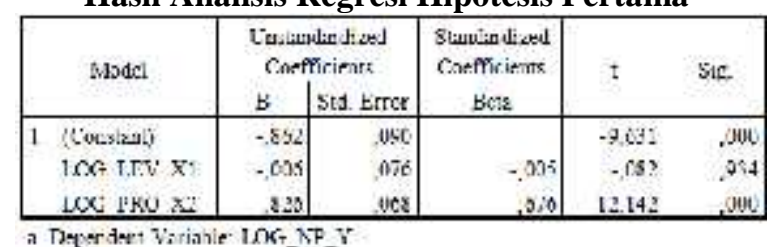

Sumber: Hasil Output SPSS 20.0 (Data diolah 2016) Dari hasil analisa dengan program SPSS pada tabel 2 di atas, diperoleh persamaan regresi $\mathbf{Y}=$ $\mathbf{0 , 8 6 2}-\mathbf{0 , 0 0 6} \mathbf{X}_{1}+\mathbf{0 , 8 2 6} \mathbf{X}_{2}+\mathbf{e}$, artinya Leverage (DER) berpengaruh negatif dan Profitabilitas (ROE) berpengaruh positif terhadap Nilai Perusahaan (Tobin's Q) pada perusahaan manufaktur yang terdaftar di Bursa Efek Indonesia tahun 2010 - 2014. 
2) Analisis Korelasi dan Determinasi

Tabel 3

Hasil Uji Koefisien Korelasi Pearson Product Moment Hipotesis Pertama

\begin{tabular}{|c|c|c|c|c|}
\hline & & 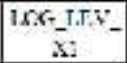 & 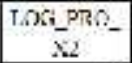 & 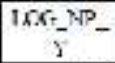 \\
\hline \multirow{4}{*}{ Tót 1.RP $x$} & Preaseu Couclatar & 1 & $0 \%$ & 번 \\
\hline & $\sin (\%$ axiles) & & .155 & 905 \\
\hline & A & $2 s 0$ & 280 & $1: 9$ \\
\hline & Peiason Coutialivi- & $.07 i j$ & 1 & $.07 g^{\prime-}$ \\
\hline \multirow[t]{3}{*}{ TOG PRO $x$ ? } & Sig. (1. lailec) & .130 & & $\cos$ \\
\hline & $x^{2}$ & 180 & $=8$ & 170 \\
\hline & l'carsun Coutalaw & $\cos s$ & $6 / 5^{-}$ & 1 \\
\hline \multirow[t]{2}{*}{ TOC NF Y } & $\sin (0$ tailot) & .705 & $\infty$ & \\
\hline & $\mathrm{x}$ & .79 & .70 & 179 \\
\hline
\end{tabular}

Sumber: Hasil Output SPSS 20.0 (Data diolah 2016)

Dari tabel 3 menunjukkan bahwa nilai korelasi Pearson untuk variabel Leverage sangat rendah yaitu 0,039 dan tingkat signifikansinya 0,303 $>0,05$ sehingga dapat disimpulkan bahwa korelasi antara Leverage dan Nilai Perusahaan sangat lemah dan tidak signifikan. Sedangkan untuk variabel Profitabilitas, nilai korelasi Pearsonnya cukup tinggi yaitu 0,676 dan tingkat signifikansinya $0,000<0,05$ sehingga dapat disimpulkan bahwa korelasi antara Profitabilitas dan Nilai Perusahaan cukup kuat dan dinyatakan signifikan positif.

\section{Tabel 4}

Koefisien Determinasi Hipotesis Pertama Model Summary ${ }^{\mathrm{b}}$

\begin{tabular}{|c|c|c|c|c|}
\hline Modal & $\mathrm{R}$ & B. Squ:asc & $\begin{array}{l}\text { Au jusles: } k \\
\text { Squar: }\end{array}$ & $\begin{array}{l}\text { Sid Frnar a } \\
\text { the Ertimatc }\end{array}$ \\
\hline & $675^{\circ}$ & 457 & .450 & 33591 \\
\hline
\end{tabular}

a. Prodictors: (Coustant). LOG_PRO_X2, LOG_LIV_X.

a. Doperdert Variatice LOC_ND_Y

Sumber: Hasil Output SPSS 20.0 (Data diolah 2016) Perhitungan koefisien determinasi pada tabel 4 menunjukkan bahwa nilai Adjusted $R$ Square cukup tinggi yaitu $0,450(45 \%)$ yang berarti variasi Leverage dan Profitabilitas dapat menjelaskan variasi dari Nilai Perusahaan pada perusahaan manufaktur yang terdaftar di Bursa Efek Indonesia tahun 2010 - 2014 sebesar 0,450 (45\%) dan sisanya sebesar $55 \%$ dijelaskan oleh faktor lainnya yang tidak dibahas dalam penelitian ini seperti Earning Per Share (EPS), Price to Earnings Ratio (PER), Price/sales ratio, dan Price Earning Ratio to Growth (PEG Ratio).

\section{3) Uji Hipotesis}

a) Uji Hipotesis $\mathbf{F}$

Adapun hipotesa yang akan diuji secara simultan adalah:

Ho : Tidak ada pengaruh signifikan dari variabel bebas terhadap variabel terikat

Ha : Ada pengaruh signifikan dari variabel bebas terhadap variabel terikat

Dengan bantuan program SPSS, maka hasil uji $\mathrm{F}$ pada penelitian ini dapat dilihat pada tabel 5 berikut:
Tabel 5

Uji F Statistik Hipotesis Pertama

\begin{tabular}{|c|c|c|c|c|c|}
\hline Waidel. & $\begin{array}{l}\text { Surn of } \\
\text { Scatercs }\end{array}$ & $\overline{c f}$ & $\begin{array}{l}\text { Shes } \\
\text { Scatert }\end{array}$ & $\bar{T}$ & Sis \\
\hline Regressior & 10.501 & 7 & 8.115 & 73,062 & $n \pi c$ \\
\hline Busiue 1 & $19,30 \mathrm{~b}$ & $1 / 3$ & .23 & & \\
\hline Total & 76.551 & 178 & & & \\
\hline
\end{tabular}

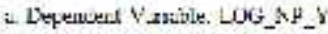

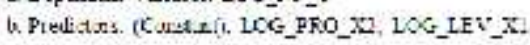

Sumber: Hasil Output SPSS 20.0 (Data diolah 2016)

Dari hasil Anova atau F test pada tabel 5 menunjukkan bahwa nilai $F_{\text {hitung }}$ sebesar 73,962 lebih besar dari nilai $F_{\text {tabel }}$ pada tingkat kepercayaan $\alpha=$ $5 \%$ dengan $\mathrm{df}_{1}=\mathrm{k}-1=2-1=1$ dan $\mathrm{df}_{2}=\mathrm{n}-\mathrm{k}-1=$ $178-2-1=175$ yaitu sebesar 3,90 dengan tingkat signifikansi 0,000 lebih kecil dari 0,05 . Hal ini berarti bahwa Ho ditolak yang berarti variabelvariabel Leverage dan Profitabilitas secara bersamasama atau simultan mempengaruhi Nilai Perusahaan pada perusahaan manufaktur yang terdaftar di Bursa Efek Indonesia tahun 2010 - 2014.

\section{b) Uji Hipotesis t}

Adapun hipotesa yang akan diuji adalah:

Ho: Tidak ada pengaruh signifikan dari variabel bebas terhadap variabel terikat

$\mathrm{Ha}$ : Ada pengaruh signifikan dari variabel bebas terhadap variabel terikat

Dengan penggunaan program software SPSS for Windows Version 20.0 pada tabel 2 di atas , maka hasil uji t pada penelitian menerangkan bahwa :

(1) Variabel Leverage mempunyai nilai $t_{\text {hitung }}=$ $-0,082$ lebih kecil dari $\mathrm{t}_{\text {tabel }}=1,97353$ dengan probabilitas signifikan 0,934 lebih besar dari $\alpha=$ 0,05. Berdasarkan nilai tersebut dapat disimpulkan bahwa Ho diterima, artinya Leverage secara parsial berpengaruh tidak signifikan terhadap Nilai Perusahaan pada perusahaan manufaktur yang terdaftar di Bursa Efek Indonesia tahun 2010 - 2014.

(2) Variabel Profitabilitas mempunyai nilai $t_{\text {hitung }}=$ 12.142 lebih besar dari $t_{\text {tabel }}=1,97353$ dengan probabilitas signifikan 0,000 lebih kecil dari $\alpha=$ 0,05. Maka dapat disimpulkan Ho ditolak yang artinya Profitabilitas secara parsial berpengaruh positif dan signifikan terhadap Nilai Perusahaan pada perusahaan manufaktur yang terdaftar di Bursa Efek Indonesia tahun 2010 - 2014.

c. Hasil Analisis Data Hipotesis Kedua

1) Analisis Regresi Berganda

$$
\text { Tabel } 6
$$

Hasil Analisis Regresi Hipotesis Kedua

\begin{tabular}{|c|c|c|c|c|c|}
\hline \multirow[t]{2}{*}{ Shovel } & \multicolumn{2}{|c|}{$\begin{array}{l}\text { Unstancarcuasd } \\
\text { Creffiliert: }\end{array}$} & \multirow{2}{*}{$\begin{array}{l}\text { Standardizsd } \\
\text { Chefficiert: } \\
\text { Bst. }\end{array}$} & \multirow[t]{2}{*}{1} & \multirow[t]{2}{*}{ Sy } \\
\hline & B & S'té. Em, & & & \\
\hline 1 (Comstart) & 074 & $n 40$ & & 858 & 65 \\
\hline Zan:UOG_1EV_XI; & 015 & .021 & .033 & 632 & .228 \\
\hline 7ssursina PRO X? & sos & mos & .711 & 19,758 & $\omega$ \\
\hline 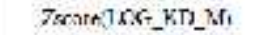 & 136 & mo5 & 3.0 & 5,159 & co \\
\hline Nosteras 1 & 050 & .030 & .208 & 2.667 & .67 \\
\hline Natecas ? & met & $m \times 5$ & 013 & ISS & 85 \\
\hline
\end{tabular}

Sumber: Hasil Output SPSS 20.0 (Data diolah 2016) 
Dari hasil uji nilai selisih mutlak pada tabel 6 di atas diperoleh persamaan regresi $\mathbf{Y}=\mathbf{0 , 0 7 4}+$ $0,015 \mathrm{ZX}_{1}+0,325 \mathrm{ZX}_{2}+0,136 \mathrm{ZX}_{3}+0,050 \mid \mathrm{ZX}_{1}$. $\mathbf{Z X}_{\mathbf{3}}|+\mathbf{0 , 0 0 5}| \mathbf{Z X}_{\mathbf{2}}-\mathbf{Z X}_{\mathbf{3}} \mid+\mathbf{e}$, artinya Leverage tidak berpengaruh terhadap Nilai Perusahaan pada perusahaan manufaktur yang terdaftar di Bursa Efek Indonesia tahun 2010 -2014 sedangkan Profitabilitas dan Kebijakan Dividen berpengaruh positif dan signifikan terhadap Nilai Perusahaan pada perusahaan manufaktur yang terdaftar di Bursa Efek Indonesia tahun 2010-2014. Selain itu, dari persamaan regresi juga dapat disimpulkan variabel Kebijakan Dividen tidak mampu memoderasi hubungan antara Leverage dan Profitabilitas dengan Nilai Perusahaan pada perusahaan manufaktur yang terdaftar di Bursa Efek Indonesia tahun 2010 - 2014.

\section{2) Analisis Determinasi}

\section{Tabel 7}

Koefisien Determinasi Hipotesis Kedua

\begin{tabular}{|c|c|c|c|c|}
\hline Morat & $\mathrm{R}$ & R Granes & $\begin{array}{c}\text { Ad isted R } \\
\text { Square }\end{array}$ & $\begin{array}{l}\text { Stat Teror of } \\
\text { the Estimate }\end{array}$ \\
\hline 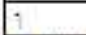 & $7 \%$ & 726 & 213 & $31<01$ \\
\hline
\end{tabular}

Sumber: Hasil Output SPSS 20.0 (Data diolah 2016)

Tabel 7 di atas menunjukkan nilai Adjusted $R$ Square sebesar 0,523 atau sebesar 52,3\% yang berarti variasi Nilai Perusahaan dapat dijelaskan oleh variasi ZLeverage, ZProfitabilitas, ZkebijakanDeviden, $\left|Z_{1} X_{1} Z_{3}\right|$ dan $\mid Z_{2}$ $Z_{3} \mid$ sebesar $52,3 \%$ dan sisanya $47,7 \%$ dijelaskan oleh variabel lain di luar model ini. Ini menunjukkan bahwa korelasi atau hubungan dalam model ini cukup kuat.

\section{3) Uji Hipotesis $\mathbf{F}$}

Adapun hipotesa yang akan diuji secara simultan adalah:

Ho : Tidak ada pengaruh signifikan dari variabel bebas terhadap variabel terikat

Ha : Ada pengaruh signifikan dari variabel bebas terhadap variabel terikat

Dengan bantuan program SPSS, maka hasil uji $\mathrm{F}$ pada penelitian ini dapat dilihat pada tabel 8 berikut:

Tabel 8

\section{Uji F Statistik Hipotesis Kedua}

\begin{tabular}{|c|c|c|c|c|c|c|}
\hline \multicolumn{7}{|c|}{ AnOS:A2 } \\
\hline \multicolumn{2}{|c|}{ Alucel } & $\begin{array}{l}\text { Sure of } \\
\text { Squarts }\end{array}$ & $u$ & $\begin{array}{l}\text { Ale-4 } \\
\text { Scruare }\end{array}$ & & $\mathrm{S}_{\mathrm{z}}$ \\
\hline \multirow{3}{*}{1} & Restraim & 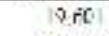 & 5 & 5000 & m & $0.000^{2}$ \\
\hline & Rsaitual & 15.560 & 173 &.$C 9 B$ & & \\
\hline & Tre-1 & 7555 & 178 & & & \\
\hline \multicolumn{7}{|c|}{ ce: Vest } \\
\hline \multicolumn{7}{|c|}{ Zesera__oc_l'tew } \\
\hline
\end{tabular}

Dari hasil Anova atau F test pada tabel 8 menunjukkan bahwa nilai $F_{\text {hitung }}$ sebesar 40,013> $\mathrm{F}_{\text {tabel }}$ pada tingkat kepercayaan $\alpha=5 \%$ dengan $\mathrm{df}_{1}=$ $\mathrm{k}-1=4$ dan $\mathrm{df}_{2}=\mathrm{n}-\mathrm{k}-1=178-5-1=172$ adalah sebesar 2,42 dengan tingkat signifikansi $0,000<$ dari 0,05 . Hal ini berarti bahwa Ho ditolak yang berarti variabel-variabel ZLeverage, ZProfitabilitas, ZKebijakanDeviden, $\left|Z_{1}-Z_{1}\right|$ dan $\mid Z_{2}$ $\mathrm{ZX}_{3} \mid$ secara bersama-sama atau simultan mempengaruhi nilai perusahaan.

\section{Pembahasan Hasil Penelitian}

\section{a. Pengaruh Leverage terhadap Nilai} Perusahaan

Hasil pengujian variabel leverage terhadap nilai perusahaan menggunakan uji $\mathrm{t}$ mempunyai $\mathrm{t}_{\mathrm{hitung}}$ $=-0,082<\mathrm{t}_{\text {tabel }}=1,97353$ dengan probabilitas signifikan $0,934>\alpha=0,05$. Hal ini menunjukkan bahwa variabel leverage secara parsial berpengaruh negatif tidak signifikan terhadap nilai perusahaan pada perusahaan manufaktur yang terdaftar di Bursa Efek Indonesia tahun 2010 - 2014. Hasil penelitian ini sesuai dengan hasil penelitian Mahendra (2011) dan Sambora, dkk (2014) yang menemukan bahwa leverage tidak berpengaruh signifikan terhadap nilai perusahaan.

Leverage dalam teori berhubungan negatif dengan nilai perusahaan. Semakin tinggi leverage maka nilai perusahaan akan semakin rendah dan semakin rendah leverage maka nilai perusahaan semakin tinggi. Leverage dalam hasil penelitian ini ditunjukkan memiliki pengaruh yang sangat rendah dan tidak signifikan terhadap nilai perusahaan. Ini mengindikasikan semakin tinggi atau rendah hutang yang dimiliki oleh perusahaan manufaktur yang terdaftar di Bursa Efek Indonesia tahun 2010 - 2014, tidak akan mempengaruhi nilai perusahaan. Besar kecilnya hutang yang dimiliki perusahaan tidak terlalu diperhatikan oleh investor, karena investor lebih memperhatikan bagaimana pihak manajemen perusahaan mengunakan hutang tersebut dengan efektif dan efisien untuk mengembangkan perusahaan dan mencapai nilai tambah bagi perusahaan.

\section{b. Pengaruh Profitabilitas terhadap Nilai Perusahaan}

Hasil pengujian variabel profitabilitas terhadap nilai perusahaan menggunakan uji $t$ mempunyai $12.142>$ dari $t_{\text {tabel }}=1,97353$ dengan probabilitas signifikan 0,000 lebih kecil dari $\alpha=$ 0,05 . Maka keputusan yang diambil adalah Ho ditolak yang artinya Profitabilitas berpengaruh positif dan signifikan terhadap Nilai Perusahaan pada perusahaan manufaktur yang terdaftar di Bursa Efek Indonesia tahun 2010 - 2014.

Profitabilitas dalam teori berhubungan positif dengan nilai perusahaan. Semakin tinggi profitabilitas maka nilai perusahaan semakin tinggi dan semakin rendah profitabilitas maka nilai perusahaan juga semakin rendah. Profitabilitas menunjukkan tingkat keuntungan bersih yang mampu diraih oleh perusahaan pada saat menjalankan operasinya. Keuntungan yang layak dibagikan kepada pemegang saham adalah 
keuntungan setelah bunga dan pajak, sehingga dengan profitabilitas yang tinggi dapat memberikan nilai tambah kepada nilai perusahaannya yang tercermin pada harga sahamnya. Dimana semakin baik perusahaan dalam membayar return terhadap pemegang saham akan meningkatkan nilai perusahaan di mata investor.

c. Pengaruh Leverage dan Profitabilitas terhadap Nilai Perusahaan dengan Kebijakan Dividen sebagai Variabel Moderating.

Hasil dari analisis pengaruh leverage dan profitabilitas terhadap nilai perusahaan dengan kebijakan dividen sebagai variabel moderating menunjukkan bahwa kebijakan dividen tidak mampu memoderasi hubungan Leverage dan Profitabilitas terhadap Nilai Perusahaan. Hal ini mengindikasikan bahwa peningkatan ataupun penurunan daripada kebijakan dividen tidak akan mempengaruhi hubungan antara leverage dan profitabilitas dengan nilai perusahaan secara signifikan. Hasil penelitian ini mendukung penelitian Mahendra (2011) yang menyatakan bahwa Kebijakan Dividen tidak mampu memoderasi hubungan Likuiditas, Leverage dan Profitabilitas terhadap Nilai Perusahaan.

\section{KESIMPULAN DAN SARAN}

\section{Kesimpulan}

a. Leverage dan Profitabilitas secara bersama-sama atau simultan berpengaruh positif dan signifikan terhadap Nilai Perusahaan pada perusahaan manufaktur yang terdaftar di Bursa Efek Indonesia tahun 2010 - 2014. Hasil penelitian ini konsisten dengan penelitian yang dilakukan oleh Sambora, dkk yang mengemukakan bahwa secara simultan Leverage (DER dan DR) dan Profitabilitas (EPS dan ROE) signifikan berpengaruh terhadap Nilai Perusahaan (Harga Saham).

b. Secara parsial, Leverage berpengaruh negatif tidak signifikan terhadap nilai perusahaan pada perusahaan manufaktur yang terdaftar di Bursa Efek Indonesia tahun 2010 - 2014. Hal ini disebabkan karena besar kecilnya hutang yang dimiliki perusahaan tidak terlalu diperhatikan oleh investor, karena investor lebih memperhatikan bagaimana pihak manajemen perusahaan mengunakan hutang tersebut dengan efektif dan efisien untuk mengembangkan perusahaan dan mencapai nilai tambah bagi perusahaan.

c. Profitabilitas secara parsial mempunyai pengaruh positif dan signifikan terhadap Nilai Perusahaan pada perusahaan manufaktur yang terdaftar di Bursa Efek Indonesia tahun 2010 2014. Hal ini terjadi karena semakin besar laba yang diperoleh perusahaan, maka kemampuan perusahaan untuk membayar return terhadap pemegang saham akan semakin baik yang pada akhirnya akan meningkatkan nilai perusahaan di mata investor. d. Hasil analisa pada analisis regresi variabel moderasi dengan metode selisih mutlak menunjukkan tabel uji signifikansi parameter individual bahwa pada taraf signifikansi 5\%, diperoleh kebijakan dividen tidak mampu memoderasi pengaruh leverage dan profitabilitas terhadap nilai perusahaan pada perusahaan manufaktur yang terdaftar di Bursa Efek Indonesia tahun 2010 - 2014. Hal ini mengindikasikan bahwa kebijakan dividen tidak mampu meningkatkan nilai perusahaan pada saat leverage rendah dan juga tidak dapat menurunkan nilai perusahaan pada saat leverage tinggi. Selain itu, kebijakan dividen juga tidak mampu meningkatkan nilai perusahaan pada saat profitabilitas tinggi dan tidak dapat menurunkan nilai perusahaan pada saat profitabilitas rendah.

\section{Saran}

a. Bagi perusahaan, agar lebih memperhatikan faktor-faktor apa saja yang dapat mempengaruhi nilai suatu perusahaan dan lebih berhati-hati dalam mengambil kebijakan sehingga tidak mengurangi nilai perusahaan. Selain itu, perusahaan juga perlu memperhatikan tingkat leverage karena tingkat hutang yang terlalu besar dapat membahayakan posisi perusahaan terutama dalam mencapai nilai perusahaan yang baik bagi pihak eksternal perusahaan.

b. Bagi para investor maupun calon investor yang mengambil keputusan investasi, disarankan untuk terlebih dahulu menganalisis tingkat profitabilitas khususnya Return on Equity (ROE) perusahaan sebelum berinvestasi karena profitabilitas sangat berpengaruh dalam menentukan harga saham dari perusahaan manufaktur yang terdaftar di Bursa Efek Indonesia.

c. Sehubungan dengan kelemahan dan keterbatasan yang dimiliki penulis, maka diharapkan bagi peneliti selanjutnya untuk memperluas bahasan mengenai rasio lainnya untuk mengetahui bagaimana pengaruh kebijakan dividen dan profitabilitas terhadap nilai perusahaan. Selain itu, penulis juga menyarankan agar penelitian berikutnya menggunakan time lag pada variabel-variabel yang akan diteliti untuk mendapatkan hasil yang lebih akurat.

\section{E. DAFTAR PUSTAKA}

Astuti, Dewi. 2004. Manajemen Keuangan Perusahaan. Jakarta: Ghalia Indonesia.

Atmaja, Lukas Setia. 2008. Manajemen Keuangan. Yogyakarta: Andi Offset.

Brigham, Eugene F. dan Joel F. Houston. 2006. Manajemen Keuangan. Buku 1. Edisi X. Jakarta: Salemba Empat.

Brigham, Eugene F. dan Joel F. Houston. 2012. Dasar-dasar Manajemen Keuangan. Edisi XI. Jakarta: Salemba Empat. 
Horne, James C. Van dan John M. Wachowicz. 2012. Prinsip-prinsip Manajemen Keuangan.

Kasmir. 2010. Pengantar Manajemen Keuangan. Edisi Pertama. Cetakan Kedua. Jakarta: Prenada Media Group.

Keown, et. al. 2004. Manajemen Keuangan: Prinsip dan Penerapan. Edisi Kesembilan. Jilid 1. Jakarta: Indeks.

Margaretha, Farah. 2011. Manajemen Keuangan untuk Manajer Perusahaan. Jakarta: Erlangga.
Edisi Ketigabelas. Jilid 1. Jakarta: Salemba Empat.

Sartono, Agus. 2008. Manajemen Keuangan. Edisi Keempat. Yogyakarta: BPFE.

Stice, James D., Earl K. Stice dan K. Fred Skousen. 2009. Akuntansi Keuangan: Intermediate Accounting. Edisi Keenambelas. Buku 1. Jakarta: Salemba Empat.

Sudana, I Made. 2011. Manajemen Keuangan Perusahaan: Teori dan Praktik. Jakarta: Erlangga. 